\title{
PENGARUH AUDIT TENURE, REPUTASI AUDITOR DAN UKURAN PERUSAHAAN, TERHADAP OPINI AUDIT GOING CONCERN (STUDI EMPIRIS PADA PERUSAHAAN MANUFAKTUR SUB SEKTOR MAKANAN DAN MINUMAN PADA TAHUN 2014-2018)
}

\author{
Adolpino Nainggolan, SE, M.Ak \\ Heriston Sianturi, SE, MM \\ adolpino_nainggolan@yahoo.co.id, bertonray@gmail.com \\ Fakultas Ekonomi dan Bisnis - Program Studi Akuntansi \\ Universitas Satya Negara Indonesia
}

\begin{abstract}
ABSTRAK
Tujuan penelitian ini adalah untuk mengetahui pengaruh audit tenure, reputasi auditor dan ukuran perusahaan terhadap opini going concern. Populasinya adalah perusahaan manufaktur sub sektor makanan dan minuman yang terdaftar di BEI pada tahun 2014 hingga 2018. Metode pengambilan sampel adalah Purposive Sampling. Teknik analisis yang digunakan dalam penelitian ini adalah analisis regresi logistik. Hasil penelitian secara parsial audit tenure tidak berpengaruh terhadap opini going concern, sedangkan reputasi auditor dan ukuran perusahaan berpengaruh terhadap opini audit going concern. Secara simultan variabel audit tenure, reputasi auditor dan ukuran perusahaan berpengaruh terhadap opini going concern sebesar $45,80 \%$, sedangkan sisanya sebesar $54,20 \%$ dipengaruhi oleh variabel lainnya yang tidak termasuk penelitian ini.
\end{abstract}

Kata Kunci: Audit Tenure, Reputasi Auditor, Ukuran Perusahaan, danOpini Audit Going Concern 


\section{PENDAHULUAN}

Perusahaan didirikan dengan tujuan untuk mempertahankan kelangsungan hidup (going concern). Kelangsungan hidup usaha selalu dihubungkan dengan kemampuan manajemen memperoleh laba agar perusahaan tersebut dapat mempertahankan kelangsungan hidup (going concern). Bentuk pertangungjawaban manajemen dalam mengelola perusahaan ditunjukkan dalam bentuk laporan keuangan. Laporan keuangan memberikan gambaran mengenai posisi kinerja perusahaan, dan perubahan posisi keuangan. Agar laporan keuangan tersebut dapat dipercaya, maka dibutuhkan laporan auditan yang diterbitkan oleh Kantor Akuntan Publik (KAP) dalam bentuk opini audit. Laporan auditan tersebut berperan dalam menjembatani kepentingan pengguna laporan keuangan dan penyedia laporan keuangan (Wulandari, 2014).

Salah satu opini yang bisa diberikan auditor adalah opini going concern. Opini going concern merupakan opini yang diterima oleh suatu perusahaan yang menunjukan adanya kondisi dan peristiwa yang menimbulkan keraguan auditor akan kelangsungan hidup perusahaan atau kemampuan entitas untuk mempertahankan kelangsungan hidupnya (Rizki dan Indah, 2014).

Opini going concern dapat dipengaruhi masa perikatan audit (audit tenure) antara suatu perusahaan dengan KAP. Apabila masa perikatan yang dilakukan dalam waktu lama akan membuat kedekatan antara klien dengan auditor, sehingga independensi dan objektivitas auditor nantinya akan terpengaruh. Pernyataan tersebut serupa dengan penilitian Al- Thuneibat et al,. (2011) yang menyatakan masa perikatan cukup lama dapat mempengaruhi independnsi dan objektivitas auditor dalam memberikan opini.

Pemberian opini going concern bukanlah suatu tugas yang mudah karena berkaitan erat dengan reputasi auditor. Penghakiman terhadap KAP sering dilakukan, baik oleh masyarakat maupun pemerintah dengan melihat kondisi bangkrut atau tidaknya perusahaan yang diaudit. Hal ini berarti reputasi sebuah KAP dipertaruhkan ketika opini yang diberikan ternyata tidak sesuai dengan kondisi perusahaan yang sesungguhnya. Auditor harus mempunyai keberanian dalam mengungkapkan permasalahan mengenai kelangsungan hidup (going concern) perusahaan klien. Auditor bertanggung jawab mengevaluasi apakah terdapat kesangsian besar terhadap kemampuan entitas dalam mempertahankan kelangsungan hidupnya dalam periode waktu pantas (Bonita Riestianiko, 2017).

Faktor lain yang mempengaruhi opini going concern adalah ukuran perusahaan. Ukuran perusahaan menggambarkan besar kecilnya suatu perusahaan yang pada umumnya ditentukan berdasarkan total asset (Seftianne, 2011), semakin besar ukuran perusahaan, maka semakin meningkat pula agency cost yang terjadi, hal ini dapat terjadi karena besarnya total asset perusahaan kecenderungan diperoleh dari pinjaman jangka panjang, dimana beban bunga pinjaman tersebut dapat mempengaruhi kemampuan perusahaan untuk mempertahankan kelangsungan hidupnya

Beberapa penelitian telah dilakukan oleh peniliti sebelumnya, namun, hasilnya masih menunjukkan ketidak konsistenan. Hasil penelitian yang dilakukan oleh Fauzan Syahputra dan M. Rizal Yahya (2017) audit tenur berpengaruh terhadap opini going concern, sedangkan penelitian M. Nur Fahmi (2015) ) audit tenur tidak berpengaruh terhadap opini going concern 
Hasil penelitian Fitria Octari Hidayanti dan Sukirman (2014) reputasi auditor berpengaruh terhadap opini going concern, sedangkan penelitian Anindya Sekar Ayu Miraningtyas dan Yudowati, S. (2019) reputasi auditor tidak berpengaruh terhadap opini going concern.

Hasil penelitian yang dilakukan oleh Ginting dan Linda (2014) ukuran perusahaan berpengaruh terhadap opini going concern, sedangkan penelitian Monica Krissindiastuti dan Ni Ketut Rasmini (2016) menunjukan ukuran perusahaan tidak berpengaruh terhadap opini going concern.

Femomena tersebut yang membuat peneliti teretarik untuk melakukan penelitian selanjutnya tentang Pengaruh Audit Tenur, Reputasi Auditor dan Ukuran Perusahaan Terhadap Opini Audit Going Concern

\section{LANDASAN TEORI}

\section{Opini Audit Going Concern}

Opini audit going concern merupakan opini audit modifikasi yang diberikan auditor bila terdapat keraguan atas kemampuan kelangsungan hidup (going concern) perusahaan atau terdapat ketidakpastian yang signifikan atas kelangsungan hidup perusahaan dalam menjalankan operasinya dalam kurun waktu yang pantas, tidak lebih dari satu tahun sejak tanggal pelaporan keuangan yang sedang diaudit (SPAP,2016).

\section{Audit Tenure}

Audit tenure adalah jangka waktu kerja sama yang terjalin diantara KAP dengan klien yang sama. Ketakutan akan kehilangan sejumlah bayaran yang cukup besar akan memicu keraguan bagi auditor untuk memberikan opini audit going concern. Di Indonesia peraturan audit tenure telah diatur didalam Peratuan Pemerintah (PP) Nomor 20/2015 Pasal 11. Peraturan ini menjelaskan bahwa pemberian jasa audit umum atas laporan keuangan dari suatu entitas dilakukan oleh KAP paling lama untuk 5 tahun buku berturut-turut. Auditor dapat menerima kembali penugasan audit untuk klien tersebut setelah 2 tahun buku tidak memberikan jasa audit umum atas laporan keuangan klien tersebut.

\section{Reputasi Auditor}

Reputasi auditor merupakan dimana auditor bertanggungjawab untuk tetap menjaga kepercayaan publik dan menjaga nama baik auditor sendiri serta KAP tempat auditor tersebut bekerja dengan mengeluarkan opini yang sesuai dengan keadaan perusahaan yang sebenarnya (Verdiana dan Utama, 2013). Menurut penelitian Badera dan Rudyawan, 2009 dalam Putri, 2014 reputasi auditor merupakan prestasi dan kepercayaan publik yang disandang auditor atas nama besar yang dimiliki auditor tersebut.

Dalam penelitian ini reputasi auditor masih diproksikan dengan The Big 4, karena KAP The Big Four berpengaruh terhadap hasil audit dan lebih banyak mendapatkan kepercayaan dari investor (Praptorini dan Januarti, 2007 dalam Ni Made Puspa Pawitri dan Ketut Yadnyana, 2015).

Alasan KAP The Big Four lebih dipercaya dikarenakan KAP The Big Four dianggap memiliki reputasi yang lebih baik dibandingkan dengan KAP Non Big Four dan memiliki sumber daya yang lebih besar dibandingkan dengan KAP Non

Jurnal Ilmiah Akuntansi dan Ekonomi Volume. 5 Nomor. 2, Agustus 2020 Hal. 77 
Big Four, sehingga dalam dalam melaksanakan audit KAP The Big Four cenderung lebih efisien dan efektif dan memiliki jadwal untuk menyelesaikan audit tepat waktu, guna menjaga reputasinya. (Praptorini dan Januarti, 2007 dalam Ni Made Puspa Pawitri dan Ketut Yadnyana, 2015). ). KAP The Big Four terdiri dari:

a. Deloitte Touche Tohmatsu, yang bekerja sama dengan Satrio Bing Ery dan Rekan serta Hermawan Juniarto \& Partners

b. Price Waterhouse Coopers, yang bekerja sama dengan Tanudiredja, Wibisana \& Rekan.

c. Ernst \& Young, yang bekerja sama dengan Purwantono, Suherman dan Surja.

d. KPMG (Klynveld Peat Marwick Goerdeler), yang bekerja sama dengan KAP Siddharta dan Widjaja.

\section{Ukuran Perusahaan}

Ukuran adalah Suatu skala dimana dapat diklasifikasikan besar kecilnya perusahaan menurut berbagai cara antara lain dengan total aset, nilai pasar saham, dan lain-lain. (Hery, 2017). Besar kecilnya perusahaan akan mempengaruhi kemampuan dalam menanggung resiko yang mungkin timbul dari segala situasi yang dihadapi perusahaan. Dimana perusahaan dengan skala besar cenderung dianggap lebih mampu mengatasi resiko-resiko yang ada. Ukuran perusahaan dapat dinilai dari total aset. Nilai aset dapat menunjukan kekayaan yang dimiliki perusahaan dalam menjalankan kegiatan operasionalnya. Ukuran perusahaan dapat dilihat dari seberapa besar atau kecil usaha yang dilakukan perusahaan. Perusahaan dengan skala besar dan pertumbuhan yang positif memberikan tanda bahwa semakin kecil kemungkinan perusahaan akan bangkrut dan dianggap mampu mempertahankan kelangsungan usahanya.

\section{METODE PENELITIAN}

\section{Desain Penelitian}

Desain penelitian yang dilakukan adalah Penelitian Kausal (Causal Research). Penelitian kausal adalah penelitian yang bersifat sebab akibat. Digunakan untuk mengetahui pengaruh antara satu atau lebih variabel bebas (Independent Variable) terhadap variabel terikat (Dependent Variable).

\section{Populasi dan Sampel}

Populasi yang digunakan dalam penelitian ini adalah perusahaan go public yang terdaftar di Bursa Efek Indonesia (BEI) dibidang manufaktur sub sektor makanan dan minuman pada tahun 2014-2018. Pengambilan sampel dalam penelitian ini menggunakan purposive sampling, Metode purposive sampling adalah teknik penentuan sampel dengan pertimbangan beberapa kriteria tertentu (Sugiyono, 2017:124).

\section{Tabel 1}

Jumlah Sampel

\begin{tabular}{|c|l|c|}
\hline No. & \multicolumn{1}{|c|}{ Kriteria } & Jumlah Perusahaan \\
\hline 1 & $\begin{array}{l}\text { Total perusahaan manufaktur sub sektor makanan dan } \\
\text { minuman yang terdaftar di BEI pada tahun 2014 sampai } \\
\text { dengan 2018. }\end{array}$ & 28 \\
\hline
\end{tabular}




\begin{tabular}{|c|l|c|}
\hline 2 & $\begin{array}{l}\text { Perusahaan yang tidak konsisten menerbitkan laporan } \\
\text { keuangan dari tahun 2014 sampai dengan 2018 dan tidak } \\
\text { diaudit oleh auditor independen. }\end{array}$ & (13) \\
\hline Jumlah Sampel Perusahaan & 5 \\
\hline Tahun Penelitian & 75 \\
\hline Jumlah Sampel Data Selama Tahun Penelitian & 5 \\
\hline
\end{tabular}

Sumber : Data diolah

\section{Teknik Pengumpulan Data}

Penelitian ini termasuk dalam penelitian kuantitatif dengan menggunakan data sekunder berupa laporan keuangan sebagai sumber data. Data sekunder yang diambil dalam penelitian ini adalah laporan keuangan perusahaan manufaktur yang terdaftar di Bursa Efek Indonesia (BEI) yang telah diudit oleh Kantor Akuntan Publik (KAP). Penggunaan laporan keuangan dalam penelitian ini adalah untuk mengukur pengaruh audit tenure, reputasi auditor, dan ukuran perusahaan terhadap penerimaan opini audit going concern.

\section{Operasional Variabel dan Skala pengukuran Variabel dependen}

Variabel dependen dalam penelitian ini adalah opini audit going concern. Opini audit going concern diukur dengan menggunakan dummy. Perusahaan yang mendapat opini going concern diberi kode 1, sedangkan perusahaan yang tidak mendapat opini going concern diberi kode 0. (Krissindiastuti dan Ni Ketut Rasmini, 2016).

\section{Variabel Independen}

\section{a. Audit Tenure}

Audit tenure diukur dengan menghitung tahun dimana KAP yang sama telah melakukan perikatan dengan auditee. Audit tenure memiliki nilai maksimum 5 sebagaimana telah diatur dalam Peraturan Pemerintah Republik Indonesia Nomor 20/2015 Pasal 11 bahwa lamanya perikatan audit antara KAP dan perusahaan paling lama selama 5 tahun berturut-turut.

Audit tenure diukur dengan menggunakan dummy. Perusahaan yang telah berganti Kantor Akuntan Publik (KAP) diberi kode 1, sedangkan perusahaan yang tidak berganti Kantor AKuntan Publik (KAP) diberi kode 0

\section{b. Reputasi Auditor}

Reputasi auditor merupakan dimana auditor bertanggungjawab untuk tetap menjaga kepercayaan publik dan menjaga nama baik auditor sendiri serta KAP tempat auditor tersebut bekerja dengan mengeluarkan opini yang sesuai dengan keadaan perusahaan yang sebenarnya (Verdiana dan Utama, 2013). Dalam penelitian ini reputasi auditor diproksikan dengan The Big Four, karena KAP The Big Four lebih banyak mendapatkan kepercayaan dari investor (Praptorini, 2007 dalam Ni Made Puspa Pawitri dan Ketut Yadnyana,(2015

Reputasi Auditor diukur menggunakan dummy, perusahaan yang menggunakan KAP The Big Four diberi Kode 1, sedangkan perusahaan yang tidak menggunakan KAP The Big Four diberi Kode 0. 


\section{c. Ukuran Perusahaan}

Ukuran perusahaan merupakan skala yang dapat mengklasifikasikan perusahaan menjadi perusahaan besar, menengah dan kecil. Total aset yang dipilih sebagai proksi atas ukuran perusahaan karena mempertimbangkan bahwa nilai aset relatif lebih stabil nilai kapitalisasi pasar dan penjualan (Azizah dan Aniskyurillah, 2014). Dalam penelitian ini ukuran perusahaan diproksikan dengan menggunakan Ln total aset. Penggunaan logaritma natural (Ln) untuk mengurangi digit data terlalu besar akan tetapi tidak mengurangi nilai yang sebenarnya.

Ukuran Perusahaan= Ln Total Aset

\section{Metode Analisis Data}

Analisis data yang dilakukan dengan menggunakan analisis regresi logistik dan pengujian hipotesis dilakukan sesuai dengan rancangan pengujian hipotesis yang telah dibuat. Data diolah dengan menggunakan program IBM StatisticalPackage for Social Science (SPSS) versi 22.

\section{ANALISIS DAN PEMBAHASAN}

\section{Pengujian Hipotesis Parsial}

Tabel 2

Variables in the Equation

\begin{tabular}{|ll|r|r|r|r|r|r|}
\hline & B & S.E. & Wald & df & Sig. & Exp(B) \\
\hline Step 1a & AT &,- 315 &, 368 &, 782 & 1 &, 436 &, 614 \\
& RA &, 594 &, 374 & 3,786 & 1 &, 038 &, 486 \\
UP & 1,281 &, 890 & 7,612 & 1 &, 006 & 12,131 \\
Constant & 6,427 & 11,894 &, 548 & 1 &, 615 & 1304,413 \\
\hline
\end{tabular}

Sumber : Output Spss Versi 22

\section{a. Pengaruh Audit Tenure Terhadap Opini Going Concern.}

Dari tabel 1 di atas, nilai signifikan audit tenure sebesar 0,436 lebih besar dari 0,05. Hasil tersebut dapat disimpulkan bahwa audit tenure tidak berpengaruh terhadap opini audit going concern. Hasill ini konsisten dengan penelitian Fauzan Syahputra dan M. Rizal Yahya (2017). Hal ini menunjukkan bahwa lamanya perikatan suatu KAP dengan klien tidak mempengaruhi prosesionalisme auditor untuk memberikan opini audit going concern

\section{b. Pengaruh Reputasi Auditor Terhadap Opini Going Concern.}

Dari tabel 1 di atas, nilai signifikan reputasi auditor sebesar 0,038 yang lebih kecil dari 0,05. Hasil tersebut dapat disimpulkan bahwa reputasi auditor berpengaruh terhadap opini audit going concern. Hasil ini konsisten dengan penelitian Fitria Octari Hidayanti dan Sukirman (2014). Hal ini menunjukkan bahwa tetap menjaga kepercayaan publik dan menjaga nama baik auditor sendiri 
serta KAP tempat auditor tersebut bekerja dengan mengeluarkan opini yang sesuai dengan keadaan perusahaan yang sebenarnya.

\section{c. Pengaruh Ukuran Perusahann Terhadap Opini Going Concern.}

Dari tabel di atas nilai signifikan variabel ukuran perusahaan sebesar 0,006 lebih kecil dari 0,05. Hasil tersebut dapat disimpulkan bahwa ukuran perusahaan berpengaruh terhadap opini audit going concern. Hasil ini konsisten dengan penelitian Ginting dan Linda (2014). Hal ini menunjukkan bahwa ukuran perusahaan sangant tinggi resikonya mendapat opini audit going concern, karena, semakin besar ukuran perusahaan, maka semakin meningkat pula agency cost yang terjadi, hal ini dapat terjadi karena besarnya total asset perusahaan kecenderungan diperoleh dari pinjaman jangka panjang, dimana beban bunga pinjaman tersebut dapat mempengaruhi kemampuan entitas untuk mempertahankan kelangsungan hidupnya.

\section{Pengujian Hipotesis Stimultan (Uji G)}

Uji Stimultan bertujuan untuk melihat pengaruh variabel Independent secara bersama-sama terhadap variabel dependent. Hasil Uji simultan dalam penelitian ini dapat dilihat pada tabel 2 berikut ini :

Tabel 3

Omnibus Tests of Model Coefficients

\begin{tabular}{|rr|r|r|r|}
\hline & Chi-square & Df & \multicolumn{1}{c|}{ Sig. } \\
\hline Step 1 & Step & 23,872 & 3 &, 002 \\
& Block & 23,872 & 3 &, 002 \\
& Model & 23,872 & 3 &, 002 \\
\hline
\end{tabular}

Sumber : Output Spss Versi 22

Berdasarkan tabel di atas, hasil signifikansi variabel audit tenur, reputasi auditor dan ukuran perusahaan sebesar 0,002 lebih kecil dari 0.05. Hasil tersebut dapat disimpulkan bahwa variabel audit tenur, reputasi auditor dan ukuran perusahaan secara bersama-sama berpengaruh terhadap variabel opini going concern.

\section{Analisis Regresi Logistik}

Berdasarkan Variables in The Equation Beta pada tabel 1 di atas, maka persamaan regresi logistik dari penelitian ini adalah:

$$
\mathrm{Y}=6,427-0,315 \mathrm{X}_{1}+0,594 \mathrm{X}_{2}+1,281 \mathrm{X}_{3}
$$

a. Konstanta sebesar 6,427, dapat dinotasikan jika variabel audit tenure, reputasi auditor dan ukuran perusahaan dianggap nol maka opini going concern adalah sebesar 6,427.

b. Koefisien regresi audit tenure sebesar - 0,315 yang berarti jika audit tenure mengalami kenaikan 1 satuan, sementara reputasi auditor dan ukuran perusahaan diasumsikan tetap, maka opini going concern akan mengalami penurunan sebesar - 0,315.

c. Koefisien regresi reputasi auditor sebesar 0,594 yang berarti jika reputasi auditor mengalami kenaikan 1 satauan, sementara audit tenure dan ukuran perusahaan diasumsikan tetap, maka opini going concern akan mengalami kenaikan sebesar 0,594 . 
d. Koefisien regresi ukuran perusahaan diperoleh nilai 1,281 yang berarti jika ukuran perusahaan mengalami kenaikan 1 satuan, sementara audit tenure dan reputasi auditor diasumsikan tetap, maka opini going concern akan kenaikan sebesar 1,281.

\section{Uji Koefisien Determinasi}

Tabel 4

Model Summary

\begin{tabular}{|l|r|r|r|}
\hline Step & -2 Log likelihood & $\begin{array}{c}\text { Cox \& Snell R } \\
\text { Square }\end{array}$ & \multicolumn{1}{|c|}{$\begin{array}{c}\text { Nagelkerke R } \\
\text { Square }\end{array}$} \\
\hline 1 & $42,180^{\mathrm{a}}$ &, 283 &, 458 \\
\hline
\end{tabular}

Sumber: Output Spss Versi 22

Tabel diatas menunjukan bahwa nilai Nagelkerke $R$ Square adalah 0,458 atau $45,80 \%$, berarti bahwa audit tenure, reputasi auditor dan ukuran perusahaan secara bersama-sama mempengaruhi opini going concern sebesar 45,80\% sedangkan sisanya sebesar 54,20\% dipengaruhi oleh variabel lainnya yang tidak termasuk dalam penelitian ini, seperti audit delay, opini audit tahun sebelumnya, dan opinion shopping, , auditor switching, return on asset dan lain sebagainya.

\section{KETERBATASAN PENELITIAN}

1. Pada penelitian ini peneliti hanya memilih tiga variabel saja yaitu audit tenure, reputasi auditor dan pertumbujan peruhaaan. Variabel-variabel lain seperti audit delay, opini audit tahun sebelumnya, dan opinion shopping, , auditor switching, return on asset dan lain sebagainya, mungkin dapat mempengaruhi perusahaan untuk melakukan opini audit going concern tidak diuji pada penelitian ini.

2. Penelitian ini hanya terbatas pada perusahaaan manufaktur subsektor makanan dan minuman yang terdapat di Bursa Efek Indonesia, sehingga hasilnya tidak dapat digeneralisasikan untuk perusahaan- perusahaan lainnya yang terdaftar di BEI

3. Keterbatasan sampel penelitian hanya 75 sampel sehingga proses pengolahan data, analisis dan interpretasi hasil dianggap kurang, terutama dalam pengolahan data.

\section{KESIMPULAN}

1. Audit tenure tidak berpengaruh terhadap opini audit going concern. Hal ini menunjukkan bahwai lamanya perikatan suatu KAP dengan perusahaan tidak mempengaruhi prosesionalisme auditor untuk memberikan opini audit going concern

2. Reputasi auditor berpengaruh terhadap opini audit going concern. Hal ini menunjukkan bahwa tetap menjaga kepercayaan publik dan menjaga nama baik auditor sendiri serta KAP tempat auditor tersebut bekerja dengan mengeluarkan opini yang sesuai dengan keadaan perusahaan yang sebenarnya

3. Ukuran perusahaan berpengaruh terhadap opini audit going concern. Hal ini menunjukkan bahwa ukuran perusahaan sangant tinggi resikonya mendapat opini audit going concern, karena semakin besar ukuran perusahaan, maka 
semakin meningkat pula agency cost yang terjadi, hal ini dapat terjadi karena besarnya total asset perusahaan kecenderungan diperoleh dari pinjaman jangka panjang, dimana beban bunga pinjaman tersebut dapat mempengaruhi kemampuan entitas untuk mempertahankan kelangsungan hidupnya

4. Hasil penelitian menunjukan bahwa audit tenur, reputasi auditor dan ukuran secara bersama-sama mempengaruhi opini going concern, sebesar 45,80\% sedangkan sisanya sebesar 54,20 \% dipengaruhi oleh variabel lainnya yang tidak termasuk penelitian ini seperti likuiditas, debt default, auditor switching, return on asset dan variabel lainnya.

\section{SARAN}

1. Penelitian lebih lanjut disarankan untuk menambahkan variabel-variabel lain diluar variabel yang telah digunakan dalam penelitian ini, seperti audit delay, opini audit tahun sebelumnya, dan opinion shopping, auditor switching, return on asset dan lain sebagainya.

2. Penelitian lebih lanjut diharapkan dapat memperluas tahun pengamatan atau objek penelitian, sehingga hasil penelitian lebih mungkin untuk disimpulkan dalam vakupan yang lebih luas.

3. Hendaknya penelitian selanjutnya lebih mempersiapkan waktu dalam melakukan penelitian empiris guna lebih meningkat perolehan data penelitian.

\section{DAFTAR PUSTAKA}

\section{Buku (Text Book)}

Agoes, Sukrisno. (2014). Auditing Petunjuk Praktis Pemeriksaan Akuntan oleh Akuntan Publik. Edisi ke 4. Buku 1. Jakarta : Salemba Empat

Arens A. Alvin, Randal J. Elder dan Mark S. Beasley. 2015. Auditing dan Jasa Assurance Pendekatan Terintegrasi. Jilid 1. Edisi Lima Belas-Jakarta. Erlangga.

Ghozali, I. (2016). Aplikasi Analisis Multivariet Dengan Program IBM SPSS 23. Edisi 8. Semarang: Penerbit Badan Penerbit Universitas Diponogoro.

Hery. (2017). Kajian Riset Akuntansi. Jakarta. Grasindo.

Mulyadi. 2010. “Auditing”.Edisi Ke-6. Salemba Empat, Jakarta.

SPAP. (2016). Standar Audit 700 Perumusan Suatu Opini Pelaporan Atas Laporan Keuangan.IAPI.

Sugiyono. (2017). Metode Penelitian Kuantitatif, Kualitatif, dan R\&D. Bandung: Alfabeta, CV.

Tuanakotta, Theodorus M. (2011). Berpikir Kritis Dalam Auditing. Salemba Empat, Jakarta.

William F. Messier et al. 2014. Jasa Audit dan Assurance Pendekatan Sistematis. Jakarta: Salemba Empat

\section{Jurnal (Journal)}

Anindya Sekar Ayu Miraningtyas dan Yudowati, S, 2019, Pengaruh Likuiditas, Reputasi Auditor Dan Disclosure Terhadap Pemberian Opini Audit Going Concern, Jurnal Ilmiah Manajemen Ekonomi \& Akuntansi, Vol 
3 No 3, STIEM, Bandung

Al-Thuneibat, A., Al Issa, R., \&Baker, R. (2011). Do Audit Tenure and Firm Size Contribute to Audit Quality .Managerial Auditing Journal, Vol. 26 No. 4, pp. 317-334.

Azizah, Rizki. dan Indah Anisykurlillah. (2014). Pengaruh Ukuran Perusahaan, Debt Default, dan Kondisi Keuangan Perusahaan Terhadap Penerimaan Opini Audit Going Concern (Pada Perusahaan Manufaktur yang Terdaftar di Bursa Efek Indonesia pada Tahun 2010-2013). Accounting Analysis Journal. Universitas Negeri Semarang

Bonita, R., P. (2017). Pengaruh profitabilitas, likuiditas, solvabilitas dan pertumbuhan perusahaan terhadap opini audit going concern. Universitas Islam Negeri Syarif Hidayatullah.

Fauzan Syahputra dan M. Rizal Yahya, 2017, Pengaruh Audit Tenure, Audit Delay, Opini Audit Tahun Sebelumnya Dan Opinion Shopping Terhadap Penerimaan Opini Audit Going Concern Pada Perusahaan Manufaktur Yang Terdaftar Di Bursa Efek Indonesia Tahun 20132015, Jurnal Ilmiah Mahasiswa Ekonomi Akuntansi (JIMEKA) Vol. 2, No. 3, (2017) Halaman 39-47

Fitria Octari Hidayanti dan Sukirman, 2014, Reutasi Auditor, Ukuran Perusahaan dan Opini Audit Tahun Sebelumnya Dalam Memprediksi Pemberian Opini Audit Going Concern, Accounting Analysis Journal, Volume No 4, Jurusan Akuntansi, Fakultas Ekonomi, Universitas Negeri Semarang

Ginting, Suriani dan Linda Suryana. (2014). Analisis Faktor-Faktor yang Mempengaruhi Opini Audit Going Concern pada Perusahaan Manufaktur di BEI. Jurnal Ekonomi Mikroskis. Vol. 4, No. 2, Hal 111-120.

Krissindiastuti, M. dan Ni Ketut Rasmini. (2016). Faktor-Faktor yang Mempengaruhi Opini Audit Going Concern. E-Jurnal Akuntansi Universitas Udayana, 14(1): h:451-481

Komang Anggita Verdiana dan I Made Karya Utama, 2013, Pengaruh Reputasi Auditor, Disclosure, Audit Client Tenure Pada Kemungkinan Pengungkapan Opini Audit Going Concern, Jurnal Akuntansi, Vol 5, No. 3, Universitas Udayana

Menteri Keungan. (2018). Peraturan Menteri Keuangan Republik Indonesia nomor 17/PMK.01/2008 tentang Kantor Akuntan Publik. Jakarta.

M. Nur Fahmi, 2015, Pengaruh Audit Tenure, Audit Delay, Opini Audit Tahun Sebelumnya Dan Opinion Shopping Terhadap Penerimaan Opini Audit Going Concern Pada Perusahaan Manufaktur Yang Terdaftar Di Bursa Efek Indonesia Tahun 2013-2015, Jurnal Ilmiah Mahasiswa Ekonomi Akuntansi (JIMEKA) Vol. 2, No. 3, Halaman 39-47

Ni Made Puspa Pawitri dan Ketut Yadnyana, 2015, Pengaruh Audit Delay, Opini Audit, Reputasi Auditor Dan Pergantian Manajemen Pada Voluntary Auditor Switching, E Jurnal Akuntansi, Vol 10 No. 1, Universitas Udayana

Putrid, Tria Widiastuti, M.Rasuli, dan Volta Diyanto. 2014. "Pengaruh Opinion Shopping, Reputasi Auditor, Disclosure, dan Ukuran Perusahaan Terhadap Penerimaan Opini Audit Going Concern pada Perusahaan 
Manufaktur 2011-2013 yang Lising di Bursa Efek Indonesia”. Jurnal Akuntansi:Universitas Riau Vol.1 No.2

Republik Indoneia. 2015. Peraturan Pemerintah No. 20 Tahun 2015 Tentang Praktik Akuntan Publik. Sekretariat Negara. Jakarta

Rizki Azizah dan Indah Anisykurlillah, 2014, Pengaruh Ukuran Perusahaan. Debt Default, dan Kondisi Perusahaan Terhadap Penerimaaan Opini Audit Going concern,Accounting Analysis Journal, Vol 3, Nomor 4, Jurusan Akuntansi, Fakultas Ekonomi, Universitas Negeri Semarang,

Seftianne dan Handayani. 2011. Faktor - Faktor yang Mempengaruhi Struktur Modal pada Perusahaan Publik Sektor Manufaktur. Jurnal Bisnis dan Akuntansi, Volume 13, No. 1, April 2011, Halaman 39 - 56.

.Wulandari, S. (2014). Analisis Faktor-Faktor yang Mempengaruhi Auditor Dalam Memberikan Opini Audit Going Concern. E-Jurnal Akuntansi Universitas Udayana. 